\title{
NUTRITION EDUCATION MODULE AND WORKBOOK DEVELOPMENT FOR PRIMARY SCHOOL CHILDREN
}

\author{
Khoirul Anwar ${ }^{1 *}$, Hardinsyah Hardinsyah², Muhammad Aries ${ }^{3}$, Hana Navratilova ${ }^{3}$ \\ ${ }^{1}$ Nutrition Study Program, Sahid University - Jakarta, ${ }^{2}$ Food Nutrition Society of Indonesia, ${ }^{3}$ Community \\ Nutrition Department, Bogor Agricultural University \\ *khoirul_anwar@usahid.ac.id
}

\begin{abstract}
Primary school students are in a period of continued growth and development after the preschool age period. However several studies have shown that children at this age are vulnerable to underand over-nutrition, which can interfere in their learning process and school achievement. The objective of this activity was to develop a nutrition education module for primary school students aged 8-12 years. This activity was held on January - August 2018 into Primary Schools of Bogor. The steps of this activity included: 1) to establish of technical working group (TWG); 2) to review existing nutrition education for primary school students; and 3) to develop student module and workbook (SMW) for nutrition education. The TWG which were formed, consists of school principles, nutrition professional society (Food and Nutrition Society of Indonesia), university staffs (Bogor Agricultural University and SAHID University Jakarta), and local government (Bogor Education Office). This activity was done collaboration with SEA-PHN. Currently, there is no activity on nutrition education at these schools, neither teacher guide for nutrition education for primary school students. The TWG developed nine topics of SMW were developed, namely balance diet and my plate, active and healthy life, cereals, fruit and vegetable, protein food, limit sugar salt and fat, choosing safe and nutritious food, food label, and summary. The SMW was designed colorfully and interestingly. Prior to final version of SMW, it was assessed to be used by school children. In conclusion, the SMW could be used to educate primary school students on nutrition.
\end{abstract}

Keywords: Nutrition education; nutrition module, school children, work book

\section{INTRODUCTION}

Over the years, the problem ofnutrition on children has become an important public health problem inSoutheast Asian countries. Malnutrition problems such as overweight, underweight, stunting, and lack of micronutrient remain a significant nutritional and health problem. About 155 million chlidren are stunted, 52 million children are wasted, and 41 million children are overweight (Development Initiatives 2017). Especially in Indonesia, stunting and overweight also still occured in children. About $30.7 \%$ children age school are stunting, $11.2 \%$ are underweight, and $18.8 \%$ are overweight (Ministry of Health 2013). Beside that, several studies have shown that children at this age are vulnerable to under- and over-nutrition, which can interfere in their learning process and school achievement (weichselbaum and buttriss 2011, Bloem et al. 2013; Prado and Dewey 2014; Sudfeld et al. 2015).Nowdays, the industrialization and market globalization have led to lifestyle changes. As a consequence, the nutritional habits have been changed, characterized by an increase of fat intake, mostly in saturated fat, along with a decrease in cereals, fruits, legumes and vegetables consumption (Kremmyda 2008). These problems is also are attributed to the lack of knowledge and practice of clean and healthy lifestyle; nutrition and health education, and lack of sanitation infrastructure and facilities (Bloem et al. 2013; Smith and Haddad 2015). This shows the need of nutrition education with better approach.

The nutrition education program for school-going children are important to be prepared well especially using a tool to easier understanding.Oldewage-Theron and Napier (2011) showed that using a interesting tools has the potential to empower children with knowledge and skills to make healthy 
food choices for future health that could result in productive workers and benefit the economy of the country.Therefore, the development of a good nutrition education module is important to create an effective nutrition education. This activity is the collaborative school child nutrition project of Food and Nutrition Society of Indonesia (PERGIZI PANGAN Indonesia), South East Asia Public Health Network (SEA-PHN), Universities and the educattion government office and the part of "Be Healthy \& Active Kids Programme”.The objective of this activity was to develop a nutrition education module for primary school students aged 8-12 years.

\section{THEORETICAL FRAMEWORK}

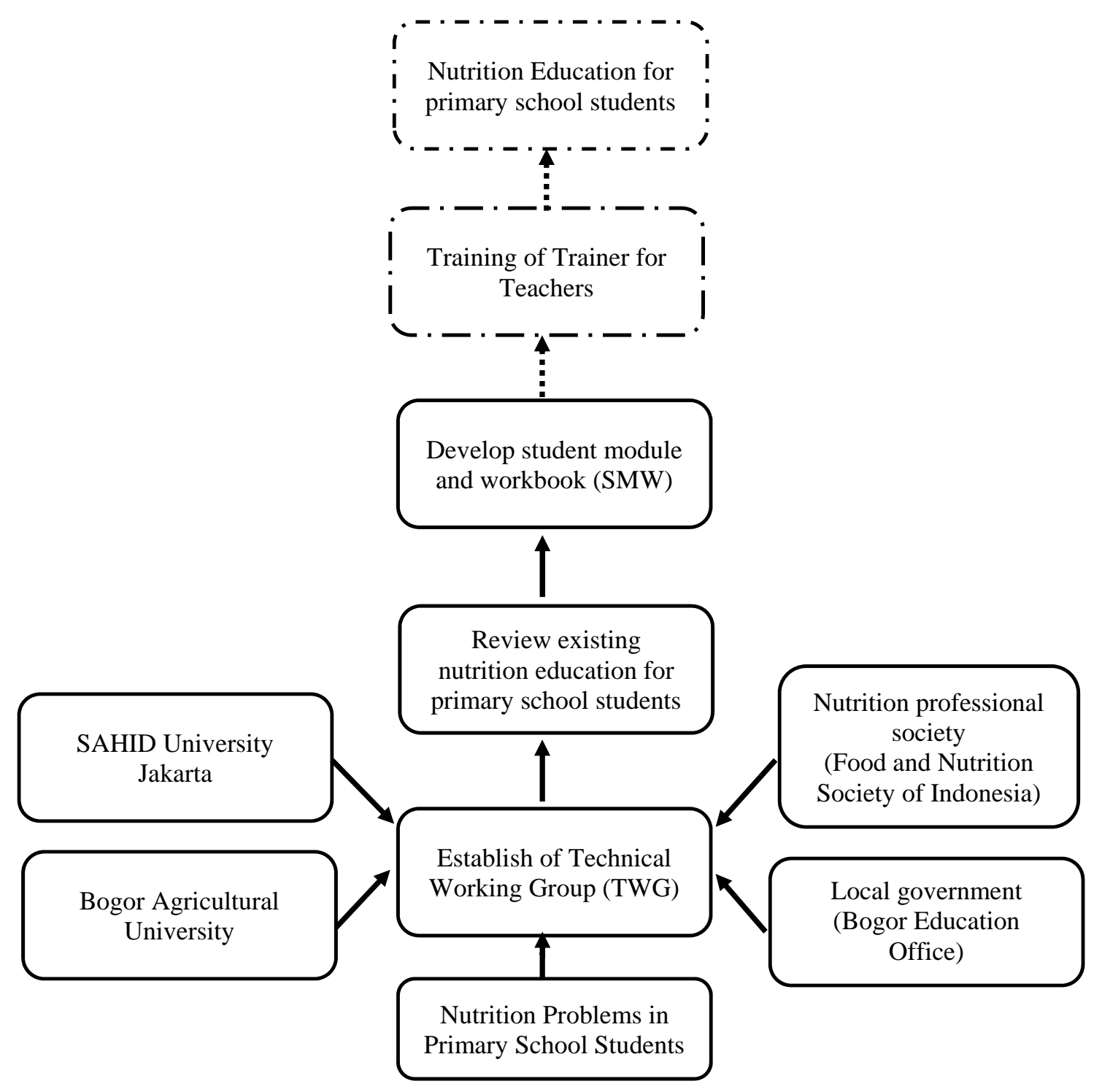

Figure 1. Theoritical framework of the development of a nutrition education module

\section{METHOD}

\section{Time and Location}

This activity was held on January - August 2018. This activity was carried out in two locations: SDN Gunung Batu 1 and 2, Bogor City, West Java and Bogor Agricultural University (IPB), Dramaga, Bogor, West Java. 


\section{Establishing Technical Working Group (TWG)}

The establishment of the Technical Working Group (TWG) was carried out before the development of the nutrition education module. TWG consists of nutrition professional society (Food and Nutrition Society of Indonesia), university staffs (Bogor Agricultural University and SAHID University Jakarta), and local government (Bogor Education Office). The function of TWG include 1) Review existing nutrition education for primary school students; 2) Developing and customization of module (student module and workbook-SMW); 3) and finalization the student module and workbook (SMW). Modules that have been developed will be tested to the teacher to be used as material for teacher training. This is needed because this module will be used as a nutrition education media provided by the teacher and then carried out monitoring and evaluation by TWG team.

\section{Reviewing existing nutrition education for primary school students}

TWG team has reviewed the existing nutrition education for primary school children. This review process is carried out in several journals, reports and activities that have been carried out in Indonesia, especially in nutritional education activities that use interactive tools that involve teachers as implementers. Teachers have an important role to play in this activities, because of the teachers can influence and give support for the children to keep the healthy lifestyle (Kupolati et al. 2015; Dudley et al. 2015).

\section{Developing student module and workbook (SMW) for nutrition education}

The primary target group of this activity is primary school children 9 years old. Based on the characteristic of targets, needed to development the interesting and enjoying tools or modules for nutrition education.The urban primary school children are likely familiar with advance information and technology, however the availability and accessibility of that technology such as DVD player and computer in every class is not possible. Therefore a combination of traditional and modern media and technology could be developed. One media that is popular among primary school children is children comics or the book that contain many cartoon characters.

The first step of developing module is choosing the interesting topics for primary school children. Based on the review, the TWG team developed nine topics of SMW namely balance diet and my plate, active and healthy life, cereals, fruit and vegetable, protein food, limit sugar salt and fat, choosing safe and nutritious food, food label, and summary. Each of these topics have a student module and workbook.

\section{RESULT AND DISCUSSION}

Currently, there is no activity on nutrition education at these schools, neither teacher guide for nutrition education for primary school students. The TWG developed nine topics of SMW were developed, namely 1) balance diet and my plate, 2) active and healthy life, 3) cereals, 4) fruit and vegetable, 5) protein food, 6) limit sugar salt and fat, 7) choosing safe and nutritious food, 8) food label, and 9) summary. The SMW was designed colorfully and interestingly. Prior to final version of SMW, it was assessed to be used by school children.
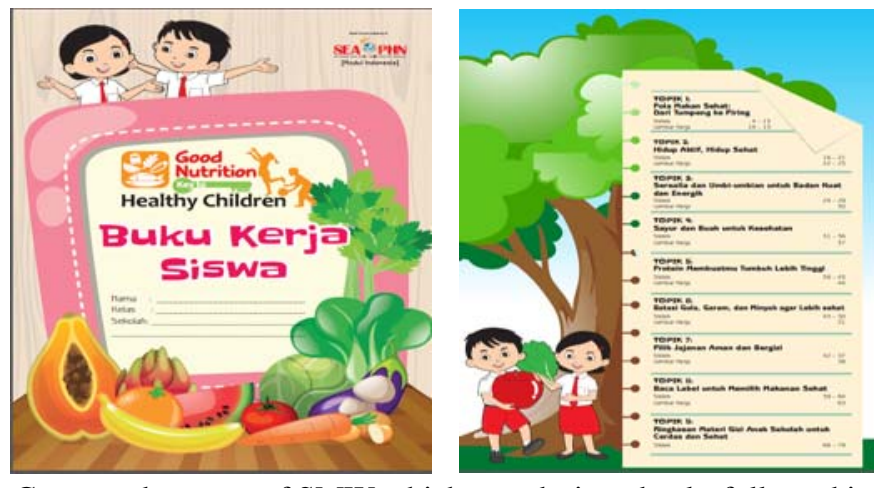

Figure 2. The Cover and content of SMW which was designed colorfully and interestingly 
Figure 2 showed that the cover and the content of SMW. The design of SMW was made colorfully and interestingly with primary school children character. These characters were made to be a healthy, active and cheerful so that it can provide an example to elementary school children. The table of contents is also presented in an interestingly so that it is easily understood by children. On the next page, a student module contains material slides and notes that can be used by students to rewrite the material submitted by the teacher if there are still things that are not understood. Different colors are also done on each topic so that the module becomes more interesting (figure 3).
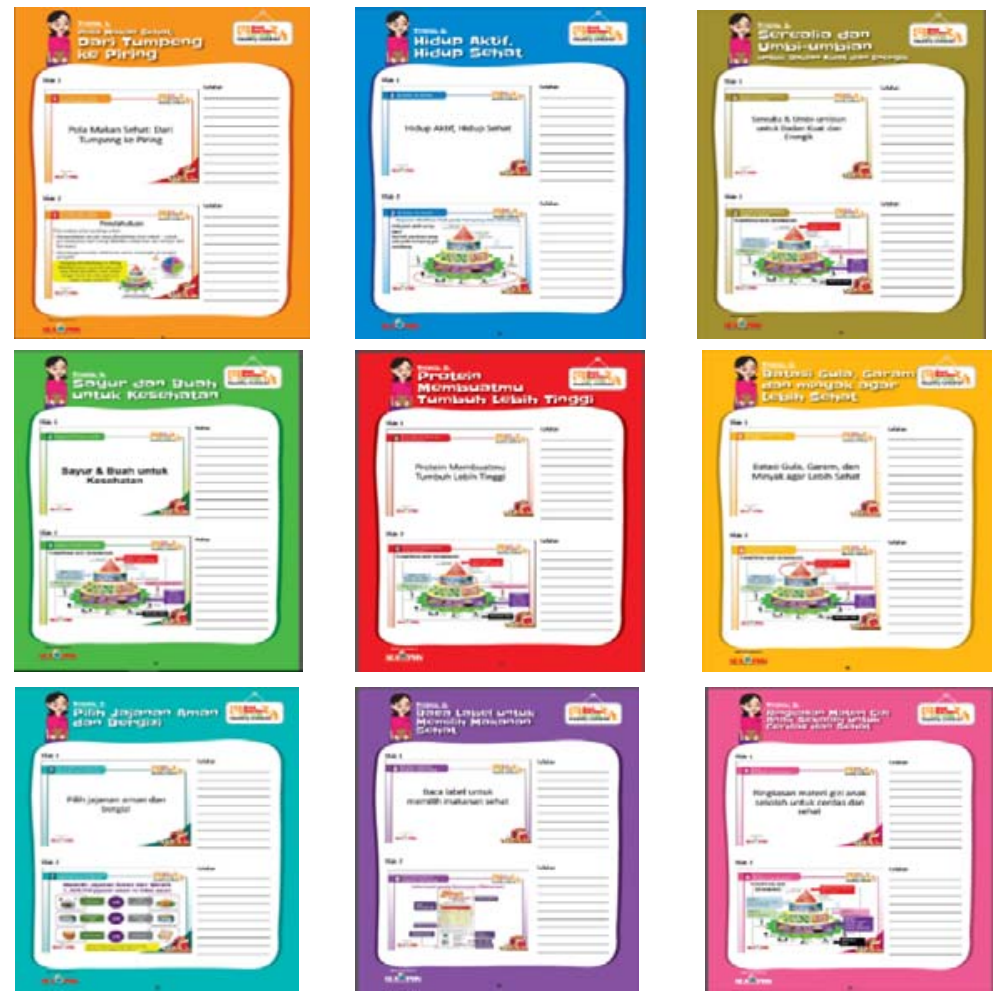

Figure 3. The student module which has a different color for each topic

In some material on student modules, children's songs are also presented at the end of the slide. This is done to make the atmosphere in the classroom more cheerful so that children become more enthusiastic and interested in participating in nutrition education activities conducted in the classroom.The example of the children's songs is presented in figure 4.
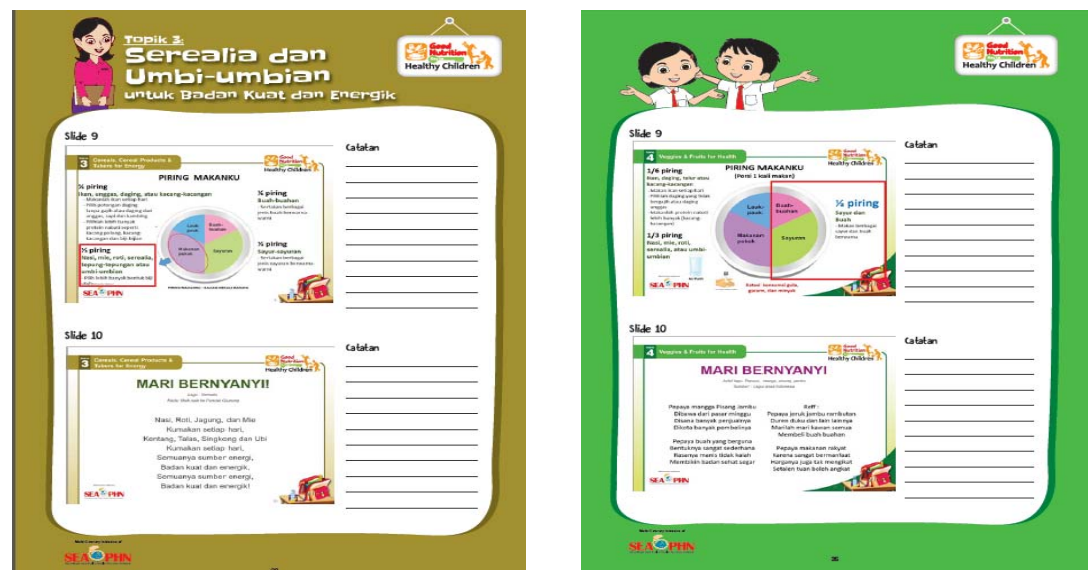

Figure 4. The example of the children's songs in student module 
On the next page, student worksheets are made as evaluation material whether students have understood the material that has been delivered during nutrition education activities. As an effort to attract students, the student worksheets are made into different games in each topic. The workbook for the first topic is "build your food pyramid". Students must fill each group of food in different colors with three types of food that are appropriate. The workbook for the second topic is "enjoying physical activity and active and healthy life guide". In the workbook "enjoy sports and physical activity" students are asked to guess the name of the sport according to the instructions given. Whereas in the workbook "active and healthy life guide" students are asked to circle activities that are not carried out at an appropriate level. The workbook for the third topic is "crossword puzzle about cereals". For this workbook, students are asked to fill the crossword puzzle according to the instructions given (Figure 5).

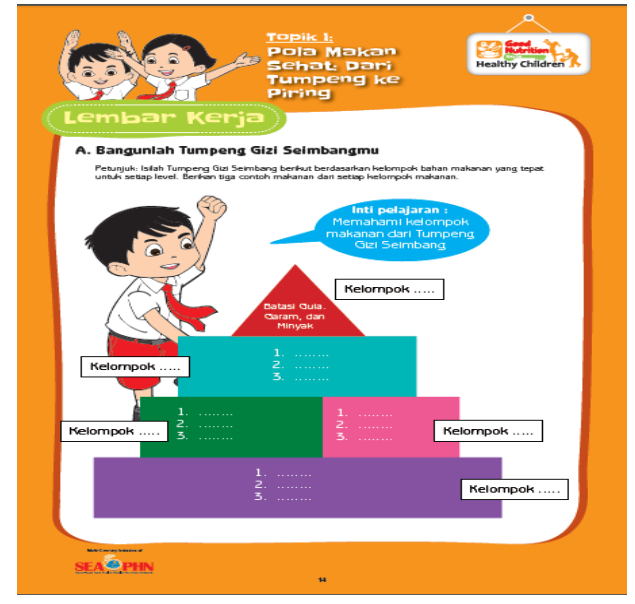

b. Active and healthy life guide

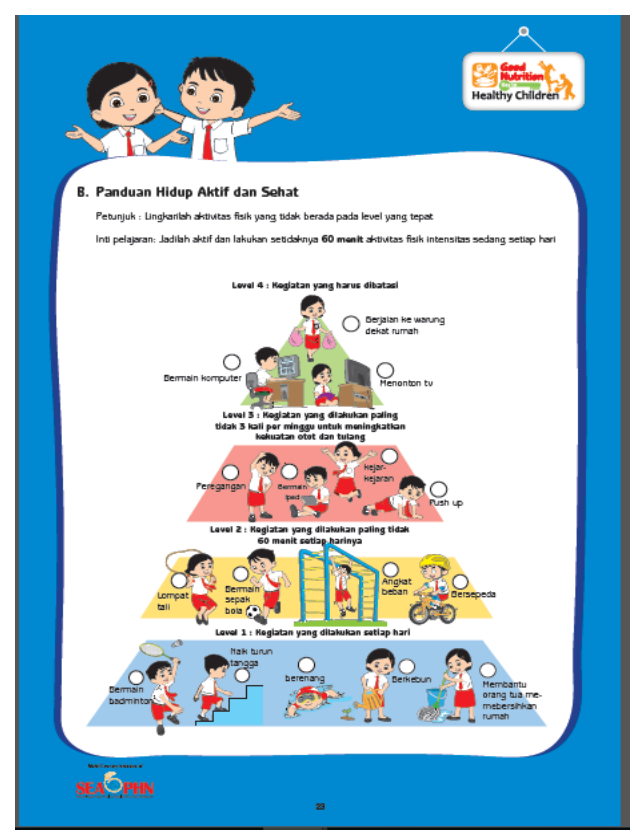

d. Build your food pyramid

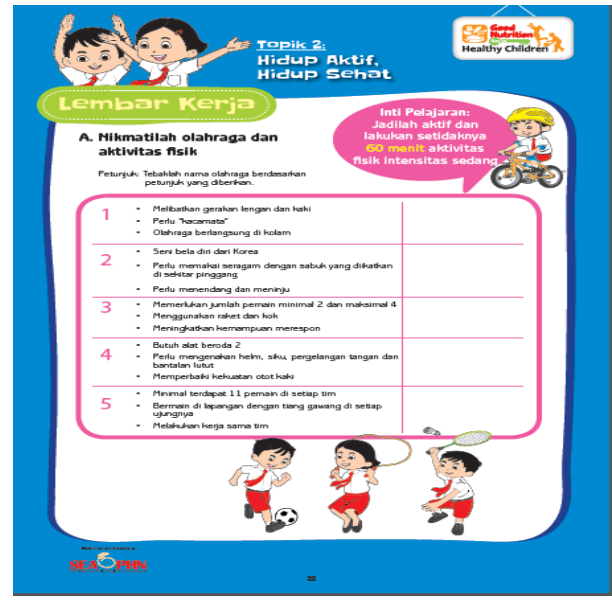

a. Crossword puzzle

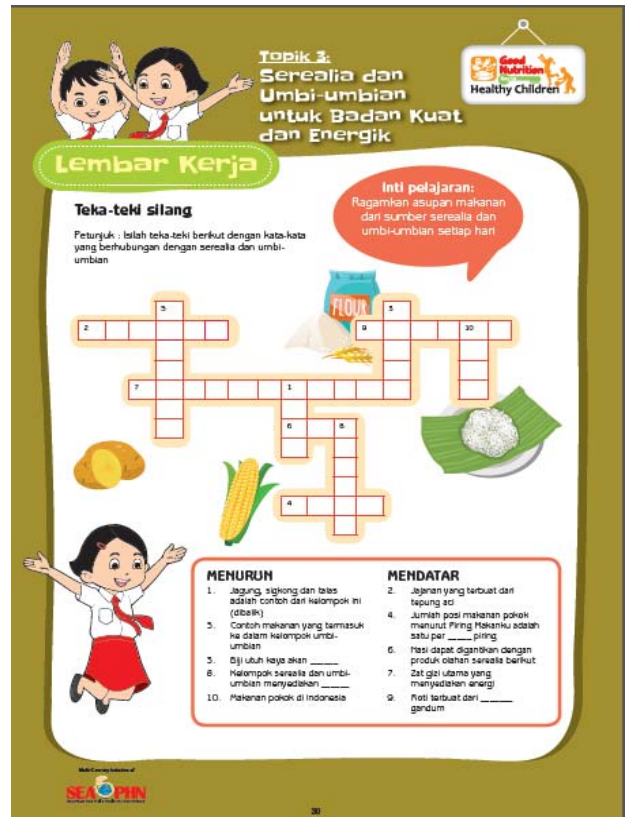

c. Enjoying physical activity

Figure 5. The student workbook for topic 1-3 
The workbook for the fourth topic is "Find your way to the food maze". Students are asked to link to all pictures of fruits and vegetables from start to finish. The workbook for the fifth topic is "random food protein puzzle". In this workbook, students are asked to reconstitute random letters to guess food sources of protein in accordance with the available images to the left of the table. The workbook for the sixth topic is "puzzle of sugar, salt and fat". Students are asked to find the name of the food ingredient in the box. Name of food ingredients can be arranged horizontally, verticallyor diagonally (Figure 6).
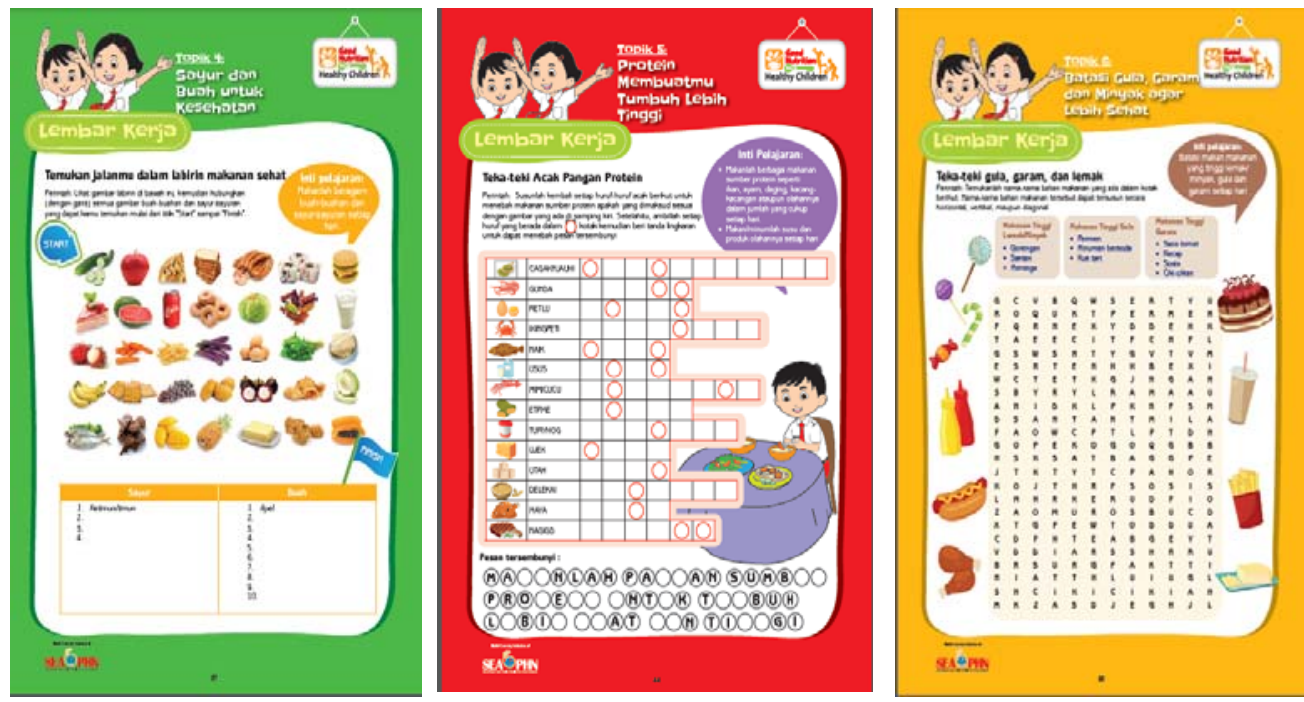

Figure 6. The student workbook for topic 4-6

The workbook for the seventh topic is "Fill in blank sentences". Students are asked to fillthe blank sentences with answers that are available correctly. The workbook for the eighth topic is "Label correctly". In this workbook, students are asked to fill in an empty label with the word given (Figure 7). There in no workbook available for ninth because the ninth topic is summary of all the topics. The colorfull and interesting workbook of this expected to make children easier to remember and understand the nutrition education material provided.
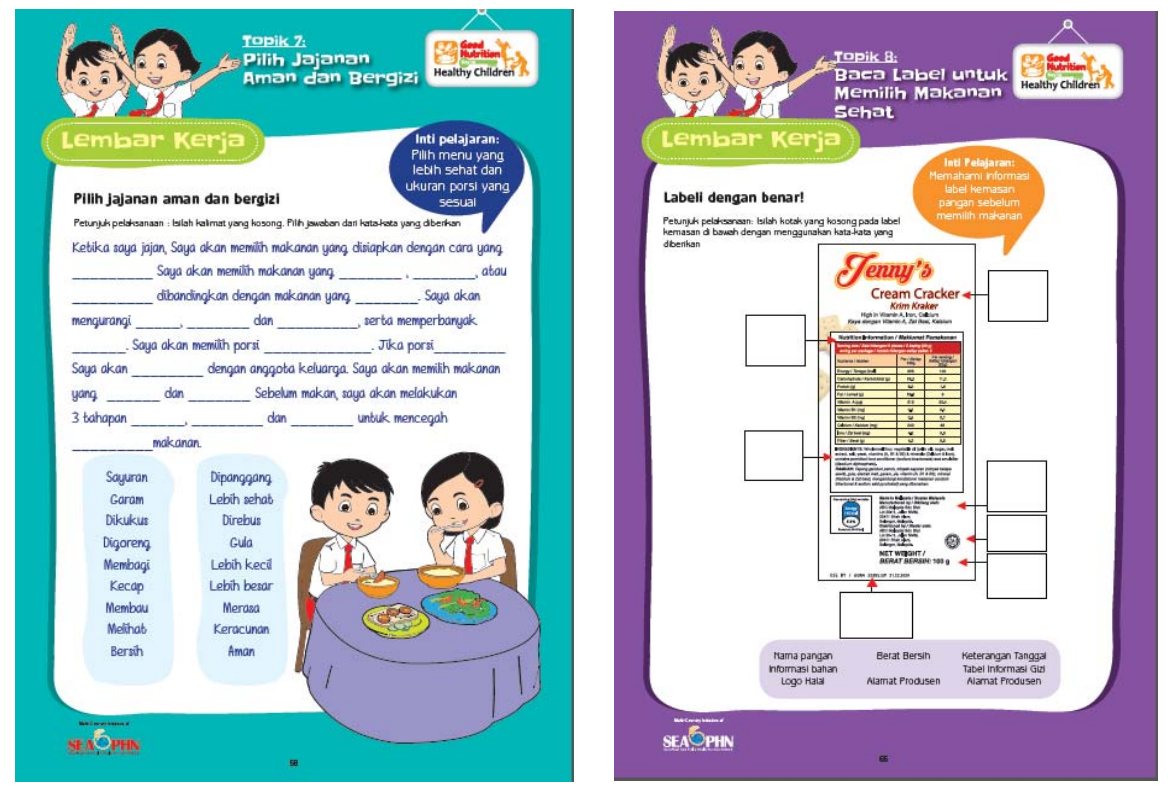

Figure 7. The student workbook for topic 7-8 


\section{CONCLUSION}

In conclusion, there is no activity on nutrition education at these schools, neither teacher guide for nutrition education for primary school students. The SMW could be used to educate primary school students on nutrition.

\section{REFERENCES}

Bartolo, M. (2014).Nutrition in Childhood. The journal of the Malta College of Family Doctors, 3(1): $12-20$

Bloem, M. W., de Pee, S., Le Hop, T., Khan, N. C., Laillou, A., Minarto, ...\& Theary, C. (2013). Key strategies to further reduce stunting in Southeast Asia: lessons from the ASEAN countries workshop. Food and nutrition bulletin, 34(2_suppl1), S8-S16.Development Initiatives.(2017). Global Nutrition Report 2017: Nourishing the SDGs. Bristol, UK: Development Initiatives.

Dudley, D. A., Cotton, W. G., \& Peralta, L. R. (2015). Teaching approaches and strategies that promote healthy eating in primary school children: a systematic review and meta-analysis. International Journal of Behavioral Nutrition and Physical Activity, 12(1), 28.

Kostanjevec, S., Jerman, J., \& Koch, V. (2011). The effects of nutrition education on 6th graders knowledge of nutrition in nine-year primary schools in Slovenia.Eurasia Journal of Mathematics, Science \& Technology Education, 7(4), 243-252.

Kremmyda, L. S., Papadaki, A., Hondros, G., Kapsokefalou, M., \& Scott, J. A. (2008). Differentiating between the effect of rapid dietary acculturation and the effect of living away from home for the first time, on the diets of Greek students studying in Glasgow.Appetite, 50(2-3), 455-463.

Kupolati, M. D., Gericke, G. J., \&MacIntyre, U. E. (2015). Teachers’ perceptions of school nutrition education's influence on eating behaviours of learners in the Bronkhorstspruit District.South African Journal of Education, 35(2), 1049.

[MOH] Ministry of Health of Indonesia. (2013). Laporan Riset Kesehatan Dasar 2013, Jakarta (ID): Balitbangkes, MOH RI.

Oldewage-Theron, W. H., \& Napier, C. E. (2011). Nutrition education tools for primary school children in the Vaal region. Development Southern Africa, 28(2), 283-292.2

Perera, T., Frei, S., Frei, B., Wong, S. S., \&Bobe, G. (2015). Improving Nutrition Education in US Elementary Schools: Challenges and Opportunities.Journal of Education and Practice, 6(30), 41-50.

Perez-Rodrigo, C., \&Aranceta, J. (2003). Nutrition education in schools: experiences and challenges. European Journal of Clinical Nutrition, 57(S1), S82.

Prado, E. L., \& Dewey, K. G. (2014). Nutrition and brain development in early life.Nutrition reviews, 72(4), 267-284.

Smith, L. C., \& Haddad, L. (2015). Reducing child undernutrition: past drivers and priorities for the post-MDG era.World Development, 68, 180-204.

Sudfeld, C. R., McCoy, D. C., Fink, G., Muhihi, A., Bellinger, D. C., Masanja, H., ...\&Fawzi, W. W. (2015). Malnutrition and Its Determinants Are Associated with Suboptimal Cognitive, Communication, and Motor Development in Tanzanian Children-3. The Journal of nutrition, 145(12), 2705-2714.

Weichselbaum E, Buttriss J. (2011). Nutrition, health and schoolchildren. Nutrition Bulletin, 36(3): 295-355. 